See discussions, stats, and author profiles for this publication at: https://www.researchgate.net/publication/332590141

\title{
MULTIMEDIA-BASED LEARNING APPLICATION DEVELOPMENT IN EDUCATION MANAGEMENT COURSES
}

Article in International Journal of Civil Engineering and Technology · April 2019

CITATIONS

0

2 authors, including:

Reza Rachmadtullah

PGRI University of Adi Buana

26 PUBLICATIONS 29 CITATIONS

SEE PROFILE
READS

2 


\title{
MULTIMEDIA-BASED LEARNING APPLICATION DEVELOPMENT IN EDUCATION MANAGEMENT COURSES
}

\author{
Ratnawati Susanto \\ Department of Elementary School Teacher Education. \\ Universitas Esa Unggul, Jakarta. Indonesia \\ Reza Rachmadtullah \\ Department of Elementary School Teacher Education. \\ Universitas PGRI Adi Buana, Surabaya. Indonesia
}

\begin{abstract}
The development of multimedia technology has promised great potential in changing the way a person learns, to obtain information, adjust information and so on. Multimedia also provides opportunities for educators to develop learning techniques to produce maximum results. For this reason, the aim of this research is to develop multimedia-based learning applications in education management courses in the Indonesian primary school superior education study program. This study uses research and development methods The research procedure used in this study is to modify the Rowntree model which has three stages, namely: product planning, development, and evaluation. In this evaluation phase, the application of Multimedia-based Learning for Education Management courses has been further validated by two multimedia experts and two instructional design experts in the field of education management. The results of this study indicate that the application of multimedia-based learning in education management courses obtained significant value so that multimedia is categorized as appropriate to use as a learning media technology.
\end{abstract}

Key words: Multimedia, education management, research, and development.

Cite this Article: Ratnawati Susanto and Reza Rachmadtullah, Multimedia-Based Learning Application Development in Education Management Courses, International Journal of Civil Engineering and Technology 10(4), 2019, pp. 1822-1827. http://www.iaeme.com/IJCIET/issues.asp?JType=IJCIET\&VType=10\&IType $=4$

\section{INTRODUCTION}

At this time, we live in the age of globalization or it could be called the era of modernization. Modernization itself in social science refers to the form of transformation from a less developed or less developed state to a better direction in the hope that people's lives will be better [1]. Modernization covers many fields, for example in the field of science and technology. In the era of modernization like now, humans are very dependent on technology 
[2]. This makes technology a basic need for everyone. The development and use of technology, has penetrated and colored all sides of people's lives, including the field of education. Today's use of technology has become commonplace, no longer a dream that is difficult to realize, including its use in the world of education. Given the use of technology for the world of education has become an inseparable part, therefore the concept of learning in higher education is inseparable from technological assistance [3].

In the century of the development of information and communication technology now all forms of information and communication technology can be obtained in a relatively easy way by using concise and sophisticated information and communication technology, judging from the trend of software and hardware development [4]. The main problem that concerns the learning activities of education management courses for a lecturer is the need to develop learning media in the form of multimedia-based applications that are integrated and connected in a computer network [5]

The birth of multimedia technology is the result of a combination of advances in electronic technology, computer engineering and software. The ability to store and process digital images in dozens of millions of colors with high resolution and reproduction of sound and video in digital form [6]. Multimedia is a concept and technology of elements - elements of images, sounds, animations and videos put together in a computer to be stored, processed and presented to form a very innovative interactive between computers and users [7]. Multimedia technology is a combination of computer technology both hardware and software with electronic technology, development and utilization of multimedia technology is widely used in almost all aspects of activities [8]. Multimedia is the use of computers to present and combine text, sound, images, animations and videos with tools and connections so that users can navigate, interact, work and communicate [9], [10]. When compared with information in the form of text (letters and numbers) commonly found on computers today, certainly information in the form of multimedia that can be received with the two human senses in a form that is in accordance with the original or in the real world (reality).

The development of multimedia technology has promised great potential in changing the way a person learns, to obtain information, adjust information and so on. Multimedia also provides opportunities for educators to develop learning techniques to produce maximum results [11]. Likewise for students, with multimedia, they are expected to be easier to determine with what and how students can absorb information quickly and efficiently. The source of information is no longer focused on text from books solely but more broadly than that. The ability of multimedia technology that has been connected to the internet will increasingly add convenience in getting the information that is expected. Audiovisual presentation or better known as multimedia makes the visualization more interesting. Communication information technology, in this case, a computer with multimedia support can present a display in the form of non-frequency, nonlinear, and multidimensional text with interactive branching of links and nodes. This display will make users (users) more freedom to choose, synthesize, and elaborate on the knowledge they want to understand [12], [13].

The types of multimedia applications are very diverse and many, the classification of multimedia can be classified from the way of presentation and purpose. Judging from the way the performance of multimedia programs is organized into; (1) Linear Program or Continuous Program, which is a continuous program from beginning to end because the information is arranged sequentially from the beginning to the end, so that the screening cannot be stopped at a random time, because the information delivered will be incomplete and unclear. Broadly speaking, the linear program consists of an opening, then followed by the contents or description of what has stated in the introduction and finally the closing section. This conclusion can be in the form of conclusions or summaries of all the descriptions. Multimedia 
programs with a linear program form can be static audio-visual programs such as multi-image slide programs, audio-visual motion, animated films, or a combination of the three media. (2) Interactive Program which is an application that can each stand alone so that the application is stopped at a random time and still gives the required information which is the smallest part or unit of the entire application. The interactive application gives many choices to the audience to choose the information they want, and from where it will start and end, or only part of the total information needed.

Many studies discuss the development of multimedia applications as a tool in learning activities, but especially in education management subjects, they are still little developed. Therefore the purpose of this study is to produce multimedia-based learning applications in education management courses. This application is expected to contribute to the development of education and learning technology especially in education management courses, and this application is expected to provide convenience for lecturers to deliver messages and information about technology-based learning materials.

\section{METHOD}

This study aims to develop Multimedia-based Learning Applications for Education Management courses. The method used in this study is Research and Development. This development research includes the process of finding newness and excellence in the framework of the effectiveness, efficiency, and productivity of the products developed. The research procedure used in this study is to modify the Rowntree model which has three stages, namely: product planning, development, and evaluation. The evaluation used is Tessmer's formative evaluation [14]. This evaluation stage is the application of Multimedia-based Learning for Education Management courses which has been further validated by two multimedia experts and two instructional design experts in the field of education management.

The instrument used in this study is to modify the multimedia assessment instrument developed by simatupang [15] and Rachmadtullah [16], the instrument of this study in the form of a questionnaire divided into two parts. The first questionnaire is aimed at instructional design experts in the field of education management who will provide an assessment based on Material accuracy aspects, Content compliance, Complete presentation of material, Suitability of practice questions with indicators. The second questionnaire is aimed at multimedia experts who will provide an assessment based on aspects of Display Design, Navigation, Animation, Text, Typography, ease of use of multimedia.

Data analysis in this study is using qualitative descriptive analysis techniques which describe the results of product development in the form of Multimedia-based Learning Applications for Education Management courses. Data obtained through assessment instruments at the time of the trial were analyzed using descriptive statistics. In this way, it is expected to facilitate understanding the data for the next process. The results of data analysis are used as a basis for revising multimedia application products developed. Data regarding the opinions or responses of multimedia experts and educational management instructional design experts were analyzed by descriptive statistics. The results of the questionnaire were analyzed by criteria namely: 4.00-3.50 Criteria Very Good, 3.49-3.00 Criteria Good, 2.99-2.50 Criteria Poor. And 2.49-0.00 criteria are not good.

\section{RESULTS}

The results of this study discuss how to design multimedia-based learning applications and how the results of the validation assessment of multimedia experts and educational instructional management design experts. At the stage of making Multimedia-based Learning application, it is designed using the adobe flash player application so that it becomes an 
application that can be used in learning activities in education management courses. This application consists of the main page containing the application usage menu, learning material menu, exit menu. The following is a multimedia display image that was developed.
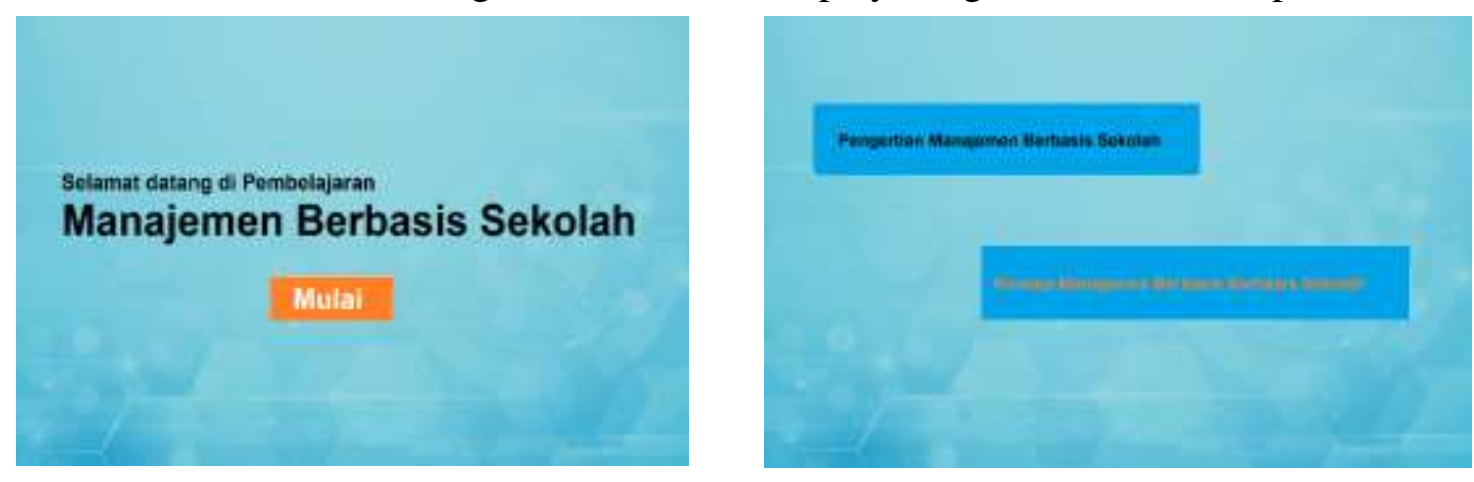

Figure 1. Display of multimedia applications developed

After the application is designed, the next stage is the formative evaluation stage of the application of Multimedia-based Learning for Education Management courses that has been designed to be rated and validated by two multimedia experts and two instructional design experts in the field of education management. The results of the assessment by multimedia experts are as follows

Table 1. Evaluation of the results of multimedia expert validation on multimedia-based learning applications developed for education management courses

\begin{tabular}{lcc}
\hline \multicolumn{1}{c}{ Rated aspect } & Average & Category \\
\hline Display Design & 3.55 & Very good \\
Navigation & 3.46 & Good \\
Animation & 3.47 & Very good \\
Text & 4.00 & Very good \\
Typography & 4.00 & Very good \\
ease of use of multimedia & 3.95 & Very good \\
\hline
\end{tabular}

Based on the results of an assessment by multimedia experts on the aspects of Display Design obtained 3.55 with good criteria. Assessment of aspects Navigation was obtained 3.46 with good criteria. Assessment of the Animation aspect was obtained 3.47 with good criteria. The assessment of the Text aspect is 4.00. Assessment on the aspect of Typography obtained 4.00 and the assessment on aspects of ease of use of multimedia obtained 3.95 with very good criteria. Based on the results of the evaluation of the six aspects of multimedia-based learning applications developed for education management courses by multimedia experts, it can be concluded that the applications of multimedia-based learning that have been designed are obtained conclusions that are worthy of use. Furthermore, the results of the instructional design validation assessment are obtained as follows 
Table 2. Evaluation of the results of Instructional Design expert validation on the content of the material contained in multimedia-based learning applications developed for education management courses

\begin{tabular}{lcc}
\hline \multicolumn{1}{c}{ Rated aspect } & Average & Category \\
\hline Material accuracy & 3.70 & Very good \\
Content compliance & 3.80 & Very good \\
Complete presentation of material & 3,55 & Very good \\
Suitability of practice questions with indicators & 3.70 & Very good \\
\hline
\end{tabular}

The results of the assessment by the design experts for instructional aspects Material accuracy have a value of 3.70 with very good criteria, in the aspect of Content compliance the value of 3.80 is obtained with very good criteria, the Complete presentation of material aspects obtained a value of 3.55 with very good criteria and subsequently on aspects of the suitability of practice questions with indicators obtained a value of 3.70 with very good criteria. Based on the results of the assessment of the four aspects of Instructional design expert validation on the content content of the material contained in multimedia-based learning applications developed for education management courses, it can be concluded that it is feasible to use.

\section{DISCUSSION}

Based on the results of the study, it was found that the application of multimedia-based learning in education management courses was obtained by the appropriate category. Because the application developer has met the standards in every aspect that has been determined, namely aspects in terms of Display Design, Navigation, Animation, Text, Typography, ease of use of multimedia, Material aspects of accuracy, Content compliance, Complete presentation of material, Suitability of practice questions with indicators. This multimediabased learning application developed provides convenience for its users, namely lecturers and students who take education management courses. Multimedia learning can be believed to provide convenience in delivering messages and provide high learning motivation because the appearance of this multimedia application is designed as well as possible so that students are happy to use it. This is also in accordance with the opinion of mayer [17] which states that the importance of multimedia-based technology as a medium or aids in learning activities because of multimedia presents and combines text, sound, images, animation, and video with tools and connections (links) so that users can interact,

\section{CONCLUSIONS}

This study produces a multimedia-based learning application that can be used in education management courses, the results of the study show that decent multimedia applications are used because they have met all aspects of Display Design, Navigation, Animation, Text, Typography, ease of use of multimedia, Material accuracy aspects, Content compliance, Complete presentation of material, Suitability of practice questions with indicators. Multimedia-based learning applications can be used using a computer.

\section{ACKNOWLEDGEMENTS}

The authors would like to thank all those who have contributed participation in this study.

\section{CONTRIBUTION AUTHOR}

The two authors together contributed to the research and writing of this report. Dr. Ratnawati Susanto in this study greatly contributed such as conducting needs analysis, gathering 
theoretical studies and write a paper managing data while Dr. Reza Rachmadtullah has a contribution to write a paper managing data and designing applications.

\section{REFERENCES}

[1] U. Beck, What is globalization? John Wiley \& Sons, 2018, 2018.

[2] J. Tondeur, J. van Braak, P. A. Ertmer, and A. Ottenbreit-Leftwich, "Erratum to: Understanding the relationship between teachers' pedagogical beliefs and technology use in education: a systematic review of qualitative evidence," Educ. Technol. Res. Dev., vol. 65, no. 3, pp. 577-577, Jun. 2017.

[3] M. D. Williams, N. P. Rana, and Y. K. Dwivedi, "The unified theory of acceptance and use of technology (UTAUT): a literature review," J. Enterp. Inf. Manag., vol. 28, no. 3, pp. 443-488, Apr. 2015.

[4] V. Vaishnavi and W. Kuechler, Design Science Research Methods and Patterns. CRC Press, 2015.

[5] G. Almerich, N. Orellana, J. Suárez-Rodríguez, and I. Díaz-García, "Teachers' information and communication technology competences: A structural approach," Comput. Educ., vol. 100, pp. 110-125, Sep. 2016.

[6] P. Legris, J. Ingham, and P. Collerette, "Why do people use information technology? A critical review of the technology acceptance model," Inf. Manag., vol. 40, no. 3, pp. 191204, Jan. 2003.

[7] R. E. Mayer, Multimedia Learning Second Edition. New York: Cambridge University Press, 2009.

[8] R. Rachmadtullah, Z. Ms, and M. S. Sumantri, "Development of computer - based interactive multimedia: study on learning in elementary education," Int. J. Eng. Technol., vol. 7, no. 4, pp. 2035-2038, 2018.

[9] T. Vaughan, Multimedia Making it work, 8th Edition. New York: McGraw-Hill, 2011.

[10] S. Nan, "Multimedia Image Technology and Computer Aided Manufacturing Engineering Analysis," in IOP Conference Series: Materials Science and Engineering, 2018, vol. 317, p. 012046.

[11] R. C. Clark and R. E. Mayer, e-Learning and the Science of Instruction: Proven Guidelines for Consumers and Designers of Multimedia Learning 3rd Edition. John Wiley \& Sons., 2016.

[12] I. F. Nuzulia, "Penggunaan Multimedia Interaktif Pada Pembelajaran Integral di Kelas Xii MAN Darussalam Aceh Besar Tahun Pelajaran 2014/2015," J. Peluang, vol. 4, no. 1, pp. 73-81, 2015.

[13] N. H. Waryanto, "Multimedia interaktif dalam pembelajaran," Universitas Negeri Yogjakarta, 2008.

[14] M. Tessmer, Planning and conducting formative evaluations. Routledge, 2013.

[15] H. A. Simatupang, "Pengembangan Media Pop-Up Pada Materi Organisasi Kehidupan Untuk meningkatkan motivasi dan Hasil Belajar Peserta Didik SMP Kelas VII," Universitas Negeri Yogjakarta, 2016.

[16] R. Rachmadtullah, "Research Instrument:CD-Based Multimedia Interactive Thematic on Integrative Learning in Elementary School."

[17] R. E. Mayer, J. Heiser, and S. Lonn, "Cognitive constraints on multimedia learning: when presenting more material results in less understanding," J. Educ. Psychol., vol. 93, pp. 187-198, 2001. 